\title{
MENTALIDADES HISTÓRICAS ERGO PSICOLOGÍA COLECTIVA: REFLEXIONES PARALELAS
}

HISTORICAL MENTALITIES ERGO COLLECTIVE PSYCHOLOGY: PARALLEL THOUGHTS

Mg. Jahir Navalles-Gómez (jahir.n@gmail.com) División de Ciencias Sociales y Humanidades, Universidad Autónoma Metropolitana-Iztapalapa (Ciudad de México)

\section{Abstract}

This present work reintroduces a pending discussion about collective psychology (the historical antecedent of the 20th century social psychology) and its implicit relation with the notion and the scenes described under historical mentalities. Bringing about a discussion on the origins of social psychology, reshaping that scene, its undercross and its projects.

Keywords: collective psychology, social psychology, mentalities, disciplinary origins, history.

\section{Resumen}

El presente trabajo reintroduce una discusión pendiente sobre la psicología colectiva (el antecedente histórico de la psicología social del siglo XX) y su relación implícita con la noción y los escenarios descritos bajo mentalidades históricas. Provocando una discusión sobre los orígenes disciplinares de la psicología social, reconfigurando ese escenario, sus entrecruces y sus proyectos.

Palabras clave: psicología colectiva, psicología social, mentalidades, origen disciplina, historia.

\section{Introducción}

Las historias entrecortadas o disimuladas de un campo de conocimiento como la psicología y la psicología social, provocan un debate al interior de la misma disciplina, y esa es mi intención en las siguientes líneas. Porque han sido impuestas, porque han sido ideologizadas a partir de la repetición acrítica de los orígenes y sus planteamientos precursores y porque estos se aceptan sin ningún reparo, por ejemplo, a partir de la publicación de dos manuales que acuñaron el nombre (Alvaro y Garrido 2003), y que desde el reconocimiento oficial de los mismos se gestaron dos versiones académicas que lo único que han generado es confusión y acólitos universitarios, allende $-\mathrm{y}$ obviando- los diversos senderos que ésta misma, la psicología social, ha transitado y en ocasiones colisionado con algún entrecruce disciplinar.

Existen recuentos históricos sobre los orígenes de la psicología y de la psicología social, unos mejores que otros, algunos detallados en extremo y otros que simplemente están saturados de obviedades y preferencias académicas de carácter loable. Pero hay otros que están empecinados en concebir una historia que legitime orígenes adecuados a sus fines y a la defensa de los paradigmas que esa misma versión 
ostente. Por eso es que a los hermanos Allport, la emulación académica de los hermanos Grimm, les dio por postular su versión histórica de la psicología social, de acuerdo a los preceptos y cánones que en la época se le exigía a cualquier campo de conocimiento, esto es, un estricto apego a los presupuestos positivistas (Boring 1950, Farr 1996).

Sin embargo, había una idea inmersa en las preocupaciones, los vaticinios y las esperanzas del cambio de siglo (véase Arciga 1989, Fernández 1989, Jahoda 1995), que se enriquece con la descripción coloquial pero insuficiente que sobre los comportamientos, las irrupciones masivas y las creencias compartidas que les delimitaban, y a las que se acudía como preámbulo para tornar comprensible lo que del siglo XX se anhelaba, latente en el ámbito psicológico y psicosocial, recreado y pensado históricamente, a la vez colindante con los inicios y la transición intelectual, afectiva y disciplinar acaecida entre el siglo XIX y el siglo $X X$. Esa idea es la de mentalidad.

Idea que se vería enriquecida a partir de un estilo literario y de las formas sociales que se provocaban o se aspiraban aprehender, y que no eran sino provocaciones históricas que intentaban aludir por la vida social, y que pocos supieron -o se interesaron por- reconocer, describir y bosquejar (Jahoda 1995, Béguin 1996, Burke 1999, White 2001, Fernández 1989, 2001), atentando contra las oficialidades históricas y reflexionando acerca de lo que la misma vida colectiva proyectaba.

En esa idea -mentalidad- se recreaba una descripción el pensamiento colectivo en los albores del siglo XX, valorándose como una aproximación a otras realidades históricas y una forma psicosocial que se veía enriquecida por los entrecruces disciplinares. Inmersa en costumbres y relatos que describían la vida social, en narrativas prosaicas y heroicas sobre tal o cual acontecimiento, en la exposición de personajes de los que se sabía generacionalmente, en las creencias sobre algo que pudo o no ocurrir, en todo ello se ubicaba la idea de mentalidad; en hábitos, historias y comportamientos que les redefinían, empero con la pretensión de una explicación a lo que sucedía en esos momentos.

La transición intelectual del cambio de siglo era ante todo una invitación a la lectura de las posibles explicaciones que se sucedían o cristalizaban en los fenómenos aludidos, y que contrarrestaban las respuestas explícitas que se buscaban a partir de la doctrina positivista, que sometía toda explicación al individuo o al organismo. Donde la psicología y la psicología social quedaban reducidas a estos "objetos de estudio", sin vislumbrar, ya sea por conveniencia o por ignorancia, que por ejemplo, una multitud no puede explicarse como una ebullición de neuronas al unísono, ya que esta misma entidad era algo más, un pensamiento y una actitud, una creencia y una desilusión, y sólo esto es lo que la hacía aparecer y desaparecer a voluntad, y no las explicaciones organicistas, biologicistas y psicologistas que se estilaban exponer.

Se requería otra manera de reflexionar sobre lo sucedido, sobre lo que se veía y contemplaba con terror o con parsimonia, con algarabía o con toda la incertidumbre posible, con la sugerencia de que eso cada vez se transformaría, dejaría de ser lo que es, y donde, en cada ocasión, seguiría siendo lo mismo, a mediano, corto o largo plazo, la dinámica y la perspectiva confirmarían los cambios y la permanencia de lo sucedido.

Desde ahí, la idea de mentalidad tendría cabida, no sólo con las multitudes y sus irrupciones, si no en las prácticas y las costumbres coloquiales, en las maneras de nombrar algo o en dejar de hacerlo así, en los miedos a lo colectivo, a lo presente, a lo futuro, y sobre ello reflexionaba la psicología colectiva de principios de ese siglo (Arciga 1989, Fernández 1989), develando un entrecruce disciplinar que habría de ser 
bosquejado paralelamente a lo dicho comúnmente, y cuya autonomía y originalidad es la que este texto convoca.

\section{Irrupciones Intempestivas: Ensayos de afectividad colectiva}

Cierto encantamiento -literario, erudito, irreverente- tendría el acudir a las multitudes, para aclamarles o para despreciarles, para hacer de las mismas la personificación de todos los males, para depositar en ellas todas las esperanzas, para desmembrarles o psicologizarles, para condensarles en sumatorias de individuos que como remitentes provocarían su desaparición. Por eso devendrían todo un best-seller novelesco y académico, por eso fueron -expresa o clandestinamente- manuscrito obligado de lectura, plasmándose en sus líneas dispares circunstancias y dotando de humor a la vida cotidiana a través de los años (Farge 1994, Chartier 2003); e irremediablemente, por eso fascinaron a Gustave Le Bon (1841-1931).

Gustave Le Bon fue un gran provocador, y eso se le agradece. Era la clase de autor que cuando alguien lo leía, la reacción inmediata era la de la inconformidad hacia sus palabras, hacia sus definiciones, hacia su conservadurismo extremo que le servía como estandarte para juzgar, pero también para reflexionar sobre el entorno; reconocimiento y antipatía que justamente acogió con todo mérito Georges Lefebvre (1874- 1959).

Lefebvre escribe su máxima obra histórica en 1932, un año después de que Le Bon muriera, descartando obviamente- una réplica personal; empero, este primer ejercicio es punto de partida para argumentar sobre la noción de mentalidades, y en específico, esto le permitió arrogarse, o mejor dicho que le asignaran, la paternidad de un escenario histórico concebido como histoire des mentalités collectives (Burke 1999:112), una idea que circunscribía las inquietudes disciplinares de la época, y es que según el rastreo histórico de Peter Burke, en la Universidad de Estrasburgo se reúnen e identifican los interesados y embelesados por elucubrar y/o bosquejar una "psicología histórica" (1999:24), configurando un apartado original preocupado por dar cauce e interpretación a los fenómenos colectivos.

Aunque es dos años después (1934) cuando Lefebvre expondría su implícita aversión a las ideas de Le Bon, a través de un artículo publicado bajo el auspicio de Henri Berr, intitulado Foules historiques, foules révolutionnaires, artículo que le avala como un interlocutor interesado por las dimensiones históricas que aduce la psicología de las multitudes (Burke 1999:32), y cuyo discreto mérito es el de ser, como lo personaliza Arlette Farge (1994: 275): “El autor [que] vuelve a introducir la dimensión histórica y estudia a las multitudes fuera de las sistematizaciones animales de Le Bon y de sus famosas teorías sobre la hipnosis colectiva y el instinto desencadenado". Siendo ésta una muy buena carta de presentación.

Caso contrario con respecto a la vida y obra de Le Bon, quien formalmente no es un psicólogo o un psicólogo social si no un "médico de provincias", signifique eso lo que signifique (Collier, Minton y Reynolds 1996: 93), personaje que se tornó más que famoso en los principios del siglo XX a razón de una reedición o plagio de ideas (Alvaro y Garrido 2003:26), concentradas en su obra La Psicología de las Multitudes (Psychologie des Foules), una especie de panfleto académico o libro de consulta universitario por el que es un autor trilladamente -y hasta fecha-multicitado (véase Moscovici 1993, Arciga 1989, Alvaro y Garrido 2003, Muñoz y Vázquez 2004). Un libro para aulas universitarias, cuya máxima virtud es que se le cita como el texto donde Le Bon desacredita a las multitudes, tachándoles de femeninas, de irracionales y de ser entidades completamente afectivas. 
Auspiciado con una carta de presentación como ésta, una que lo dibuja como un tipo por demás antipático y ultraderechista, existe otra, la que proponen Collier, Minton y Reynolds, y que resume de manera erudita las intenciones y el estilo del autor, a saber: "La Psychologie des Foules es racista, sexista y de tono absolutamente conservador. El racismo y el sexismo eran muy frecuentes a principios de siglo, pero el trabajo de Le Bon destaca incluso en este clima particular" (1996:96). Una descripción que intenta resaltar no al personaje sino al contexto sociohistórico bajo el que él mismo escribía y redactaba sus máximas académicas.

Como sea, aún cuando la celebridad de Le Bon se circunscribe a la mención continua a su libro sobre las multitudes, él mismo sobresale porque fue un autor polifacético, prolífico a más no poder. Suárez (2006:3536), hace un somero recuento de la obra del francés, reintroduciéndole paso a paso y sin omitir sus excesos, recapitulando aquellos temas entre los cuales fondeaban la pluma y las simpatías de aquel, lo que sirve para detenernos en una obra que redacta (c. 1906), y que era su versión de La Revolución Francesa y de una Psicología de las Revoluciones, trabajo que lo encamina a reelaborar (en 1911) un libro con título propicio para justificar los amotinamientos: Les Opinions et les Croyances (Las Opiniones y las Creencias).

Es en estos dos últimos libros citados donde hace explícitas algunas ideas que ya con antelación habría dispuesto cuando ahondaba en la dinámica de las multitudes, ideas que se arraigan cual prolegómenos hacia el origen psicosocial de las mentalidades, exhortando bajo esa alusión, tanto los comportamientos como las actitudes, su transmisión y su permanencia, su validez en un determinado momento, su transformación gradual conforme la misma situación o el acontecimiento descrito fuesen modificados.

Su aportación al origen psicosocial de las mentalidades se localiza en las tipologías que expone conforme a su evidente aparición histórica alrededor de la Revolución Francesa, a su asentamiento y difusión en las conciencias, reconociendo categorías de grupos sociales así como de comportamientos específicos, asegurando que todo eso no es más que un asunto de creencias, gestado y vuelto permanente por férreos creyentes (Le Bon 1939:13); atrayendo adeptos convencidos con ella o algunos otros más que simplemente se adaptan para sobrevivir o para saciar sus necesidades, adjudicándole una responsiva a esos tiempos revolucionarios, a saber: "En tiempos normales el entorno varía poco de modo que, por regla general, observamos una sola personalidad en la gente que nos rodea. Algunas veces, sin embargo, sucede que observamos varias que, bajo ciertas circunstancias, pueden reemplazarse entre sí" (Le Bon 1939: 65).

En la propuesta de Le Bon, las mentalidades absorben al poder y a las instituciones, las asambleas, las convenciones, los tribunales, a los militares; las formas de gobernar, desde la Monarquía hasta la Democracia; desde los líderes hasta difundirse en la masa revolucionaria.

Suponiendo una colectividad afectiva, inmersa en sus propios sentimientos, en sus ganas de atentar unos contra otros, en la preeminencia del odio sobre la estabilidad, en las envidias de las clases bajas hacia la nobleza, en el desprecio de la nobleza a las clases bajas, en los orgullos heridos que detonan cualquier conducta, en la vanidad, la ambición y los celos; empero, circunscribiéndose al mayor de ellos, a aquel que podría movilizarles o hacerlos impasibles, aquel que podría erosionarles o hacer de los grupos entidades insensibles, el miedo que sería una recreación continua de lo sucedido, y que a las multitudes dotaría con míticas poses de heroísmo, aunque también personalizaría algunas irrupciones con el dejo manifiesto de una cobardía colectiva. 
Al proponer sus tipologías, Le Bon reconoce que aún cuando son ficticias, estas vuelven explícitos los elementos que las identifican, que en ocasiones comparten o en otras se yuxtaponen, creando conflictos a partir de las dinámicas que cada una prodiga, revelando comportamientos y actitudes al resguardo de una creencia, a saber, la mentalidad mística, la mentalidad jacobina, la mentalidad revolucionaria y, finalmente, la mentalidad criminal.

En la mentalidad mística está la atribución de poderes y fuerzas a entidades supraindividuales, encarnados en ídolos o fetiches, en consignas, frases o fórmulas, que permean a cada individuo o grupo deslumbrado, "adosada a los sentimientos y a los apasionados impulsos que persigue" (Le Bon 1939:74); sobre la segunda tipología, la de la mentalidad jacobina, Le Bon señala que es ésta la mentalidad más difundida durante la Revolución Francesa, una mentalidad supuestamente adscrita en la razón, sin embargo, es una especie de creencia la que se deriva de la misma, la creencia en nuevas creencias, según lo dicho por el autor: "el jacobino es un místico que ha reemplazado las antiguas divinidades por nuevos dioses" (Le Bon 1939:81).

Pero es al remontar la mentalidad revolucionaria cuando sugiere que casi en todas ellas un manto místico les resguarda, y en específico en ésta, ya que los actos de sublevación contra el orden establecido simplemente aguardan por una creencia que les de cauce, según Le Bon, se da a nivel de colectividades, impulsadas por una mística "obsesionada con ideas fijas" (1939:84), proclive a seducir las conciencias; la última mentalidad que sugiere Le Bon, la mentalidad criminal, es la mentalidad que personifican los personajes liminales, un grupo social frecuente y cotidiano durante el periodo revolucionario, que servía de primer frontera o barricada de la misma multitud.

Esos son los personajes que siempre ha despreciado Le Bon, que le repugnan en todo su conservadurismo, de los cuales habla sólo para vilipendiarlos sin ocuparse de sus causas y su presencia, para él son la escoria de la vida social, a saber: "Todas las sociedades civilizadas arrastran fatalmente tras de sí un residuo de degenerados, de inadaptados, afectos de diversas taras. Vagabundos, mendigos, ladrones, asesinos, vagos, que constituyen la población criminal de las grandes ciudades" (1939:85). Y es ésta la mentalidad que siempre se ha temido, pero es la que más se adecua a la noción primigenia de mentalidad. La de la asociación de mentalidad con chusma o con una entidad instintiva, primitiva, soez o vulgar. Contracara a la idea de razón, ya que ésta siempre se define como un asunto estrictamente individual y personal.

\subsection{Creencias y miedos sociales; ecos e intrigas}

Las colectividades creen en todo, en lo que sea y en lo que les convenga creer. Les encantan los rumores, el contagio, el pensamiento en común. Se consumen y se reivindican en su propia literatura (Chartier 2003, Delumeau 2002, De Paz 2003). Refieren acontecimientos que creaban historias y relatos donde las multitudes eran sus protagonistas. Quedaban embebidas con aquellos emplazamientos colectivos que escudriñaban las experiencias que las hacían convocarse, los hábitos que se transmitían generacionalmente, los relatos que procuraban hacer comprensibles los paisajes cotidianos, y que les caracterizaban aún sin solicitarlo, tal cual lo comparte Arlette Farge (1994:187): "son de hecho siempre diferentes y comparten una misma convicción: la de ser legítimas, formarse con todo derecho y tener un significado. Estudiar a las multitudes es empeñarse en comprender de qué manera una población en movimiento piensa y colige a partir de la ansiedad por descifrar y hacer suyos los acontecimientos que se brindan a sus ojos". 
Esas eran las multitudes que fascinaban con su andar, o con su estancia en cualquier lugar, y que serían el referente obligado de algunas disciplinas que las definieron sutilmente, tal como lo hizo Moscovici al delimitarlas como: "Un grupo humano en efervescencia, un constante hormiguear, tal es la multitud" (1993:13). Destilando escenarios posibles o contingentes que describirían, legitimarían o proyectarían dinámicas y procesos psicosociales al abordar la vida social.

Multitudes y mentalidades, no son sólo afectividades y exposiciones de furia, rabia y descontento, son éstas mismas consecuencias y nuevos proyectos, horizontes distintos que estarían esperanzados porque a partir de su irrupción la realidad pueda ser modificada, trastocada, y donde esa transformación se esperaría los afectase a todos. Así es como algunos autores intentan reflexionar acerca de esa literatura sobre las multitudes, en ocasiones con buena fortuna, en otras más invocando los elementos afectivos que dan vida y permanencia a la presencia de una multitud (Farge 1994, Moscovici 1993, Rudé 1998, Muñoz y Vázquez 2004).

Y eso se volvió interesante para todos, desde los cándidos que compartían y transmitían esa misma idea o imagen, hasta aquellos que intentaron explicarla o consolidarla en un escrito. Ubicando algunos senderos de interlocución interdisciplinar realizados en la época (reintroducidos como trinchera temática), empero, lo anterior intenta ejemplificar las formas que la mentalidad adquirió en diversos estudios, siendo un referente teórico amplio y profundo que recubre toda una serie de procesos y dinámicas presentes y veladas de la vida y las relaciones sociales, de los avatares -históricos, psicosociales o afectivos- que implica la descripción y comprensión de la colectividad.

Se devela así un contexto intelectual que acoge de buena manera esa primera reflexión de Lefevbre, a la cual arriesgan a identificar, sin demeritarle, como influenciada por el trabajo precursor de Marc Bloch sobre los rumores y las actitudes colectivas (Burke 1999:24), como sea, es en El Gran Pánico de 1789 donde la preeminencia de personajes liminales hacen gala de sus expresiones, formas de comportarse y de reaccionar ante las historias y murmuraciones que se les transmiten, a las cuales estas mismas deforman y banalizan, de las cuales abreva una realidad incoherente pero a la cual se apegan para existir.

Lefebvre no debatía sólo contra Le Bon, si no contra el pensamiento conservador de una época, contra el rechazo y la xenofobia de toda una nación, y que permeaba los ámbitos académicos, que intentaban explicar esa realidad, círculo vicioso que simplemente legitimaba el status quo. Sin embargo, es Le Bon, en las dos obras suyas citadas, quien estipula la importancia de los comportamientos colectivos, de las desventajas y secuelas que acarrean, de los pretextos -afectivos o morales- que los componen, haciendo coincidir sus reflexiones sobre las multitudes con un caso concreto, anteponiendo su ley de la unidad mental para describir la inmanencia y disolución de alguna multitud; empero, lo que hace es argumentar por los diversos emplazamientos que devienen las mentalidades, esto es, la mentalidad de la raza, la mentalidad del pueblo, la mentalidad de la masa, la mentalidad popular (1939:90-91), insinuaciones teóricas que acogen tanto actitudes, afectos y conductas manifiestas sobre y entre la permanencia de un fenómeno social.

A lo cual respondió Lefebvre de la siguiente manera, dividiendo y entrelazando dos escenarios para bosquejar la presencia y comprensión de las multitudes: uno, del hambre manifiesta de los grupos humanos de las ciudades y las campiñas, catapultándole como la respuesta lógica hacia la pregunta por el qué o quién fueron los detonantes que fomentaron la aparición de personajes liminales, entes desprotegidos por las instituciones de beneficencia que aparecían y se desvanecían de un poblado a otro, independientemente de 
su latencia (e insuficiencia) en algunas ciudades seleccionadas; del cobijo al desdén, del refugio a la repulsión (Lefebvre 1986:20).

Según lo concibe el mismo autor, la dinámica era ésta: "los miserables salían de sus aldeas y erraban muchas leguas a la redonda. Ese vagabundeo los desmoralizaba [...]. Entonces nacía el miedo” (p.21). Postulando una explicación lógica, y de la cual abrevaban nuevas historias, audiencias que las consumían y especuladores aristócratas y profanos, plebeyos y religiosos- que les maximizaban y recuperaban de acuerdo a sus intereses (pp.179, 188-189, 207).

Y entre el hambre que potenciaba la errancia, la mejor opción que existía era la de movilizarse en grupo o en solitario entre ciudad y ciudad, de camino en camino, y de historia en historia, teniendo como consecuencia el transformarse y asumirse cínicamente como vagabundo y como bandido, de ser uno a ser otro, capaz de actuar de cualquier manera (p.24). Ciertamente, si no cabría el respeto y la compasión para los primeros entonces se exigiría temor y terror por intermediación de los segundos, por eso se volvió una alternativa de supervivencia, por convicción o por exclusión institucional.

Los personajes concibieron así un afluente de creencias colectivas alrededor de sí mismos, latentes en sus comportamientos y actitudes, que poco a poco fueron conocidas y auspiciadas, ocasionalmente promoviéndolas como una rúbrica grupal, la mayoría de las veces con la evidente intención por defender la clandestinidad (p.46-47). El hambre, ese primer escenario en el que Lefebvre se adentra, se difumina en los actos que el pueblo realiza para evitarle, saqueando, robando y usurpando localidades, derrumbando imaginarios lugares (p.130-131), proveyendo a la historia de nuevos relatos, proyectándose en "el eco de las revueltas" (p.248), en las ansias y provocaciones que posiblemente lograrían trascender, "y [que] dio origen a muchos relatos detallados" (p.266).

Cómo lo hacían es un asunto interesante, máxime cuando lo que se pretende es identificar lo que el autor sugirió como preámbulo a la idea de mentalidad, localizándole en los lugares y en los recuentos, en la transmisión constante de un escenario a otro, del campo a la ciudad, de la ciudad al campo, en la tradición oral como único medio de credibilidad que legitimaba la creencia compartida (p.103), en los rumores que de tanto repetirse se asumían como verdades, y que no eran si no la atmósfera que pululaba en los abastos y los mercados a los cuales acudían los campesinos, o en la misa dominical donde se promovían ciertas conductas, y que ya, exaltados los ánimos y candelas se explotaban en las tabernas.

El segundo escenario que Lefebvre describe es la creencia en un complot, un complot aristócrata, al cual los propios campesinos temían, odiaban y percibían socialmente, y paradójicamente, al que también se rendían los aristócratas, gestando un pánico colectivo que se alimentaba recíprocamente. Sin ser muy perspicaz, es posible señalar que los dos grupos sociales estaban compartiendo semejanzas y coincidencias: “Para nosotros no cabe la menor duda: en el origen de esos terrores hay siempre el temor hacia un enemigo [...]. Además del sentimiento de inseguridad que lógicamente despertaba la situación económica y las circunstancias políticas, hay en el origen de los pánicos la idea de que un partido o una clase social amenaza la vida y los bienes de la mayoría de la nación, a veces con ayuda del extranjero. Este temor universal y siempre idéntico, da a las alarmas locales, cuya ocasión e importancia son variables, su valor emotivo y su expansión" (p.78). 
Toda esa atmósfera que los mantenía aterrados permitía la conjunción de las inconformidades y del levantamiento en armas que preconizaban los campesinos y los desplazados, así como de las fortificaciones, las huidas del reino, las escoltas extremas, que la aristocracia ostentaba. "Basta con un individuo sospechoso o una nube de polvo, o con menos todavía -un ruido, una luz, una sombra-, y ya están seguras de que el peligro acecha. Más aún: interviene la autosugestión y creen ver y oír" (p.70).

Los rumores eran los que -para Lefebvre- sustentaban la mentalidad colectiva, aún sin describirla como tal, el historiador más bien aboga por lo que estaba detrás cuando "se hablaba de... se espera que... se dice que..." (p.82), escenas que volvían permanente la idea del complot aristócrata, que destilaban desconfianza y murmuraciones por todos lados. Pensamiento local que a fuerza de la difusión de sus temores cobijó un pánico colectivo más dilatado -y ambiguo- que sus propias preocupaciones.

Los miedos locales y aledaños se extrapolaron, circunscribiéndose a los relatos y en las crónicas de los viajeros, en las imágenes que cada cual recogía (p.187), concibiendo alarmas sublimes que al transgredir las fronteras trastocaban inercias locales, rebasando lo que las correspondencias institucionales o las epístolas transmitían, sea porque estas tardaban demasiado en llegar a su destino, sea porque la tradición oral se volvió el medio de comunicación más efectivo para despejar y recrear conjeturas. Así, todos eran sospechosos de mentir.

Una acción que tenían ya demarcada los bandidos, los vagabundos y los personajes liminales que se especializaron en supervivir a través de los ecos de los eventos sucedidos, ellos, quienes "eran la población flotante de París" (p.179), eran los que definían las situaciones locales, sea para beneficio propio, sea porque se habían infiltrado en las instituciones, concibiendo la clandestinidad, diseminando andares y actitudes, proscripciones y justificaciones.

Los bandidos, los vagabundos y todo aquel que se asumiera como personaje liminal fueron los que jugaron con las informaciones y los que se regodearon con los actos, ellos fueron los encargados de ampliar, difundir, abastecer y delimitar lo que Lefebvre llama "la imaginación popular" (p.222, 224) o "la credulidad popular" (p.278).

En suma, El Gran Pánico de 1789 es ante todo una oda a los rumores y a los temores locales ubicados espacio-temporalmente, interesado en los grupos sociales que dieron pauta a las presencias multitudinarias que se personificaron cabalmente en la Revolución Francesa, sin embargo, eso no lo exime de ser el recuento ameno de las acciones, comportamientos y actitudes que estos mismos grupos representaron, avalados en una creencia, que ocasionalmente se cristalizaba en una realidad, pero que las más de las veces no eran sino datos chuscos y pintorescos (como las polvaredas hechas por el ganado, las fogatas de unos solitarios, las sombras en el bosque, los ruidos cercanos, los disparos sin sentido), los que provocaban que las conciencias se pusieran alertas a lo que ocurría, y que a partir de ello se desplegaban los saqueos, los robos, o la preservación de sus propiedades. En esa obra se habla de una creencia popular que cree en sí misma.

Una esperanza y no fatalismos -como los que propugnaba Le Bon- era lo que servía de trasfondo a la obra de Lefebvre, quien sabía que su obra adolecía de ejemplos coloquiales y de la expresión corriente de los actos que realizaron los grupos sociales; claridad metodológica que fue considerada y debatida en las mismas entrelíneas de su proyecto histórico, y que hizo explícito al señalarlo: "y en lo que respecta a la 
explicación del gran pánico, lo que tiene importancia no es la realidad sino la idea" (p.83, cursivas agregadas).

De antemano el autor sabía que las realidades eran seducidas por sus temores, miedos y terrores, que cada personaje al que se hiciera alusión era parte de un pensamiento social que les describía y les delimitaba, los rumores podían ser posibles verdades porque las verdades sólo podían compartirse en rumores y no por imposiciones, y el pánico era creíble porque era accesible, tal cual lo señala el autor: "Y en verdad ¿qué es el gran pánico sino una gigantesca 'noticia falsa'?” (p.103).

Sutilmente Lefebvre dejó lo urgente y priorizó lo importante, las maneras de pensar colectivas en un período histórico delimitado, los afectos que les merman y que enriquecen las acciones, sin ningún descalificativo hacia lo que él describía como la mentalidad compartida, sin suponer escenarios futuros; empero, lo que puede decirse de la reflexión de Lefebvre queda corto ante lo que Marc Bloch en una reseña dijo: "La mayor originalidad del método de Lefebvre radica, precisamente, en la orientación con que ha estudiado este fenómeno. Partiendo de todo este conjunto de hechos menores, cuyo significado profundo se encontraba oculto por su apariencia inmediata y su carácter pintoresco, el autor, buscando progresivamente su explicación, nos hace penetrar en el corazón de la sociedad francesa de la época, en su estructura íntima y en el entramado de sus múltiples corrientes" (Bloch 1999:242).

Irónicamente, la aparición de esta obra fue la respuesta desde la disciplina histórica a aquello que en las primeras décadas del siglo XX se convirtió en parte de los "best-sellers académicos", esto es, los estudios circunscriptos al análisis de las masas y las multitudes, particularmente los trabajos de corte conservador realizados por Gustave Le Bon (Suárez 2006), fascinantes y tendenciosos, proclives párrafo tras párrafo a postular a las multitudes como aquellas entidades psíquicas de las que habría que avergonzarse o lamentarse cada vez que apareciesen, caso contrario a lo que hizo Lefebvre, quien ante la irracionalidad con la que se les definía intentó escudriñar en la volátil lógica de las acciones y comportamientos de masas (Burke 1999:32), a partir de una idea: mentalidad.

Los historiadores se interesaron por la irrupción y por el ocaso de las multitudes, entidades que eran teorizadas desde un emplazamiento académico distinto, uno que iba a contracorriente de los campos de conocimiento que estaban en plena consolidación, o eso se intentaba, empero es a partir de las reflexiones de ese campo relegado donde multitudes y mentalidades coinciden teórica y ejemplarmente, y de la mano de esas disertaciones históricas están los orígenes de la psicología colectiva.

A la distancia se podría criticar como un mero desplante académico el hecho de citar historiadores para confirmar planteamientos psicosociales, pero en defensa del presente texto, uno podría señalar que en sus orígenes la psicología social, no era simplemente aquella que se refería a esas entidades supraindividuales y de difícil aprehensión como lo eran las multitudes, y que mucho menos la psicología social se reduce a lo que los manuales dicen sobre la misma, empero la psicología social tiene otros orígenes, y estos pueden ser rastreados a partir de discutir con los límites impuestos a la misma disciplina, epistemológicos y ontológicos, por tanto, plantear una epistemología de la psicología social implica historizar junto con su propia historia y con la presencia o relegación de sus conceptos. 


\section{Entrecruces psicosociales; interlocuciones históricas}

Será otro escenario el que complementará aquella velada aproximación entre la historia y otras disciplinas, y para el caso que nos atañe, el entrecruce de la psicología social y las reflexiones históricas, la cual se exhibe a partir de un desacuerdo, mejor dicho, una crítica inconformidad o tal vez una especie de pataleta académica, la cual logró repercutir en las reflexiones que en la época se realizaban, pero ante todo logró aglutinar a muchos de los que con esta estuvieron de acuerdo, develándose como un antecedente intelectual que señalaba que la historia podría exponerse a partir de otros principios tanto teóricos como metodológicos, y que siendo críticos podría abracar más de lo que se decía podría reconocer.

La inconformidad mencionada tuvo su autor intelectual en un discípulo común tanto de Durkheim como de Levy-Bruhl, que respondía al nombre de Francois Simiand (1873-1935), con formación académica adicional en economía (Le Goff 1978a:279), cuya embestida se dirigió hacia lo que en la época se conocía como historia política. Una versión histórica de aproximación a la realidad, que de manera hegemónica desacreditaba todo aquello que no se apegara a sus cánones. Y lo hizo como lo hubiera hecho cualquiera que estuviese alejado de las premisas y del escenario de la disciplina histórica de la época, esto es, con la tácita percepción de que a todos los historiadores solamente les interesaba realizar una clase de historia, la citada historia política.

Destronarla, según dicen (Le Goff 1978a:279), fue el primordial objetivo. Razón por la cual su ofensiva fue dirigida hacia lo que él llamó "los tres ídolos de la tribu de los historiadores", y que a decir del recuento expreso de Peter Burke estos serían: "Según Simiand había tres ídolos que era menester derribar. Estaba el 'ídolo político', 'esa preocupación perpetua por la historia política, por los hechos políticos, por las guerras, etc., que da a esos sucesos una exagerada importancia'. Estaba también el 'ídolo individual', en otras palabras, el énfasis excesivo puesto en los grandes hombres [...]. Por último, estaba el 'ídolo cronológico', a saber, 'la costumbre de perderse uno en los estudios sobre los orígenes'” (Burke 1999:18-19).

Y en la crítica de Simiand están inmersas sus propuestas, esto es, para el primer punto, la intención era contrarrestar esa exagerada relevancia depositada sólo en "lo político"; en el segundo punto, reconoce en otro escenario el contrapeso a ese ídolo individual, en aquello que históricamente se podría determinar como "una institución, un fenómeno social, una relación que se ha de establecer" (Le Goff 1978a:279); para finalmente, en el tercer punto, reintroducir, más allá de "lo cronológico" a su contraparte, esto es, "al tipo normal, buscándolo y determinándolo en la sociedad y en la época en que se encuentra" (Le Goff 1978a:279).

Queda claro que las críticas no sólo provienen de la comunidad de historiadores hacia su propia disciplina, si no que pareciera que era más un descontento generalizado el que atravesaba a las ciencias humanas y sociales, y con la complicidad de los inconformes, los relegados, sus argumentos y sus publicaciones. Por ello es que cabe resaltar la trinchera desde la cual esta crítica irrumpió en el escenario académico, esto es, fue en la Revue de Synthése Historique (Revista de Síntesis Histórica), fundada en 1900, donde esto se logró.

La peculiaridad de esta revista es que en ella encontraban cobijo y exposición todas aquellas colaboraciones hechas desde cualesquier ámbito disciplinar, esto con la intención de cimentar una psicología "histórica" o “colectiva" (Burke 1999:19, Moya 1996:66). Responsable directo del proyecto fue aquel anteriormente citado Henri Berr (1863-1954), profesor de retórica y filósofo (Corcuera 2000:159), un personaje poco famoso a quien no se le ha hecho real justicia por sus aportaciones al ámbito de las ciencias humanas y 
sociales, sería por decisión propia o por una especie de olvido institucional, o como dice Jacques Revel (2002:49): "[Henri] Berr sigue esperando su historiador". Como sea, su instancia editorial recubría parte de los intereses e inquietudes de alguno que otro comprometido en ello, "su revista de carácter militante estaba abierta a los artículos polémicos y tuvieron cabida practicantes de todas las disciplinas sociales" (Corcuera 2000:160).

\subsection{Henri Berr y la síntesis histórica: consecuencias}

Sin excedernos demasiado, la Revista de Síntesis Histórica se proclamó como el espacio adecuado para las inquietudes y disidencias teóricas entre los estudiosos de principios del siglo XX, cuyo trasfondo velado sería el de acogerse como el lugar "donde debían codearse, procedentes de todas las disciplinas miembros del establishment universitario, pero también algunos marginados (en concreto Durkheim y los durkheimianos, presente como grupo)" (Revel 1978:81). Una acotación que esclarece las pretensiones manifiestas de Henri Berr, esto al ampararse en la fortaleza intelectual, genuinamente adquirida, del grupo más importante en la Francia de aquellos tiempos.

Y entre los interesados en abordar los fenómenos históricos bajo una concepción interdisciplinar contraria a lo realizado en generaciones pasadas, quedan expuestos los precursores de un proyecto por demás interesante, que a lo largo del siglo XX (Burke 1999, Aguirre 2005), se caracterizaría por ser uno de los estandartes de la investigación innovadora en la disciplina histórica. Sin embargo, ese mismo proyecto es parte de un legado interdisciplinar enfocado en el análisis de las sociedades humanas, en su transición y permanencia, en su conformación como entidades psicosocialmente estables a partir de sus significados y símbolos, de las formas de relacionarse y del compartir experiencias.

Responsables directos fueron Lucien Febvre (1878-1956) y Marc Bloch (1886-1944). Empero, ese legado indirectamente se configura, en un extremo, a partir de lo realizado por Henri Berr dentro de su proyecto editorial, donde reivindicaba a la historia como el máximo referente, y que como acotaría Revel con respecto a las intenciones del coordinador del proyecto: El hecho histórico tenía que ser repensado en función de un tema en continuo progreso en el tiempo [...] esta unidad se identificaba con una psicología histórica unificadora y la historia con una ciencia de los comportamientos" (Revel 1978:81).

Un ejercicio algo impresionante y presuntuoso, que sólo pudo ser acotado a partir del proyecto histórico de Bloch y Febvre, condensadas en un proyecto editorial que se aventuraron a nombrar como Annales $d^{\prime}$ Histoire Économique et Sociale (Annales de Historia Económica y Social), retomando el formato interdisciplinar de espacio de discusión crítica como aquel otro de propósito explícito coordinado por Henri Berr, asimismo, acuñando un nombre en honor de la aspiración que habría ostentado, desde su círculo disciplinar, el geógrafo Paul Vidal de la Blanche (Burke 1999:28).

Aunque lo que sobresale más allá del formato de publicación y de la línea editorial que habrían de seguir, serían los remitentes de la vida colectiva, acuñando las ideas respecto a cohesión y solidaridad social, o hacia el método comparativo, o acudiendo a la memoria social como fuente histórica, entre muchos otros.

En párrafos anteriores señalamos que Henri Berr estuvo empecinado en provocar que el conocimiento histórico fuera la guía de las ciencias humanas y sociales, pero para eso tendría que acotar el cómo es que esto se lograría, con respecto a esa obra enciclopédica antes mencionada, y remitiéndonos al primer tomo, esto es lo que Berr señala: “Algunas ideas presidirán el conjunto: pero no serán ideas dominadoras, 
impuestas a los colaboradores y, por éstos, a su vez, a los hechos; serán, mejor, ideas experimentales, hipótesis inmanentes a la obra y sometidas a la comprobación de los hechos por el trabajo libre y la soberana autonomía de los colaboradores" (1925: VII).

Con una invitación de esas características casi cualquiera se sentiría incluido a participar, decisión que dependía de su afinidad al proyecto teórico al que el mismo Berr exhortaba, a saber, un párrafo largo, que vale la pena citar en su íntegramente: "Sin pretender que el método de síntesis científica esté actualmente fijado en Historia, al menos de una manera definitiva, se puede admitir siquiera como una hipótesis a comprobar, que los hechos con los que está tejida la evolución humana se pueden reducir a tres órdenes muy diferenciados. Unos, son contingentes; otros, son necesarios; otros responden a una lógica interna. Parece acertado que se aprovechen y se concilien todas las tentativas de explicación más opuestas entre sí, intentando probar que todo el contenido de la evolución humana entre en esos cuadros generales de la contingencia, de la necesidad y de la lógica; parece que por esta división tripartita, la Historia encuentra al mismo tiempo su articulación natural y todo su alcance explicativo. Esta división, en efecto, abre profundos puntos de vista sobre la causalidad. Invita a buscar en la masa de los hechos históricos, para desembrollarla, tres especies de relaciones causales: simples sucesiones en las que los hechos son sencilla y puramente determinados por otros; relaciones constantes, en las que los hechos están ligados unos a otros por necesidades; un encadenamiento interno, en el que los hechos están unidos por razones. Desde este punto de vista sobre la naturaleza de las causas que concurren en la Historia, aparece la síntesis, difícil sin duda, pero concebible" (Berr 1925: IX).

En suma, el historiador Berr, y su proyecto de síntesis histórica, bosquejan un apartado distinto para aproximarse a las realidades sociales e históricas, y lo hace de tal forma que va engarzando cada uno de los elementos que componen esas mismas realidades, algo que es considerado a partir del papel que juegan las contingencias, esto es, cada una de estas reconocida, ubicada y categorizadas, son la deducción de lo que sucede y le importa a las conciencias compartidas, dispuestas en escenas fortuitas, en personificaciones que posiblemente permean a toda una época, en formas de pensar y comportarse en un determinado tiempo y lugar, en la valoración de los limitantes geográficos y culturales, emplazamientos que dispondrían las dinámicas a seguir: "Las contingencias modifican la estructura de las sociedades humanas, repercuten sobre las instituciones u obran directamente sobre ellas. Son en número infinito en la Historia; pero pueden ser reducidas a ciertas categorías generales: acontecimientos fortuitos, papel de los individuos en cuanto tales, disposiciones colectivas temporales, condiciones étnicas y geográficas. [...] Desde el mismo punto de vista pueden escogerse, los individuos y los acontecimientos: unos son insignificantes mientras otros tiene una importancia considerable" (Berr 1925: XII-XIII).

Al final, la sugerencia que hace Berr despliega un entrecruce y una amplitud entre escenarios a convocar, considerando por supuesto la sistematización de cada uno de los escenarios, y la guía e interlocución desde cada unos de los elementos, circunstancias, vínculos e intromisión personificada. No se trata de abarcarlo todo, se intenta establecer un dialogo con las más de las partes implicadas, a saber: "es preciso dejar que vuelva a caer en el olvido una parte de lo que se ha sacado del mismo" (Berr 1925: XIII).

\subsection{Mentalidades Expuestas: algunos proyectos}

A partir de la introducción de la noción de "mentalidad" se logra consolidar el proyecto de "los Annales", esto porque a través de los años, sendos estudios se han realizado al interior de sus páginas, cada uno intentando ejemplificarlo en diversos fenómenos históricos a los cuales cada cual habría acudido (Burke 
1999), respecto a ello el maestro Carlos Aguirre ha señalado (2005:39), que es en la tercera generación de los Annales donde se volverían populares y celebérrimas las disertaciones respecto a una "historia de las mentalidades", sin olvidar que es en la plétora de investigaciones correspondientes al citado emplazamiento donde las críticas, desilusiones e imposiciones temáticas han devenido (Burke 1999:217, Ortega 1991:94), o mejor dicho opacado, la versión primigenia de la noción de mentalidad. Pero como la intención aquí no es sino la de acudir a lo que la mentada noción sugiere como argumento psicosocial no nos ocuparemos de aquella generación famosa que ostenta tal reconocimiento.

"Mentalidad" se sugiere así, como la configuración histórica referente a los procesos psicosociales que describen la vida colectiva, o los lazos afectivos en los cuales permanece, o las formas de transmisión de significados compartidos, o la identificación de cada grupo social o colectividad y el sentido de pertenencia que cada una dispone alrededor de sus propias construcciones simbólicas y materiales, asimismo se despliega en la validez temporal de signos y sentidos comunes, presente a partir de la prácticas sociales, en las costumbres, entre las leyendas y desde los mitos, bosquejando en cada ocasión un escenario donde se reconocen y se recuperan remembranzas vueltas comportamientos y sentires. Mentalidad es una idea colectiva, es una idea recurrente de atmósfera social.

"Mentalidad" deviene en un apartado original y autónomo que podría ser reconocido como un escenario gentil proclive a una psicología colectiva o psicología histórica, recreando una versión primigenia de la misma, fluctuando entre la historia, la sociología y la psicología (Duby 2004, Le Goff 1980, Burke 1987), reestructurando un apartado teórico para una psicología social interesada en los horizontes de la vida colectiva gestada a largo plazo, anclada en las parábolas compartidas, en las significaciones mutuas, en la transmisión de sistemas simbólicos, en las prácticas sociales que las sustentan, esto porque cada acontecimiento o fenómeno social que logra describirse a partir de esta noción, sugiere a la vida social como una remembranza afectiva de las costumbres y los significados deferidos en un periodo específico, circunscrito a los juicios, actitudes y comportamientos, que un determinado grupo, comunidad o colectividad transmita o asimile espacio-temporalmente.

A saber, el pensamiento que piensa una colectividad, con el que se describe a sí misma y con los detalles que agrega con cada narrativa, en la edificación de una ciudad, su derrumbamiento, su continuidad a partir de los relatos; el pánico compartido, transmitido y heredado a partir de una historia; en la algarabía, las galimatías, el rechazo o los juicios compartidos hacia un héroe o personaje concebido por todos; a través de los recorridos, los asentamientos, las aglomeraciones que se convocaban mutuamente; esos son extractos de mentalidades.

\section{El deambular entre mentalidades}

Pocos textos trascendieron como un estudio enfocado propiamente a la noción de mentalidad, convenientemente se pueden señalar los realizados de manera primigenia por esos dos historiadores empecinados -Febvre y Bloch- por reformular las aproximaciones históricas en el siglo XX. Por su parte, el mayor de ellos (Febvre) se ubica como el autor que cuenta con más obras al respecto, una, la que acude a la vida y obra social de Martín Lutero, editada en 1928, y una más que se torna punto clave, titulada El Problema de la Incredulidad en el Siglo XVI: La Religión de Rabelais, que salió a la luz en 1942; por otro lado, a Bloch se le reconoce como el gran precursor de esta clase de estudios, todo gracias al nivel de discusión (Ginzburg 1984, Toubert 1988, Le Goff s. d.), en el cual centra sus reflexiones para así bosquejar sutilmente la noción de mentalidad, configurada magistralmente a lo largo de las páginas de su libro de 1924 sobre las 
creencias en el "toque real", llamado ampliamente Los Reyes Taumaturgos. Estudio sobre el carácter sobrenatural atribuido al poder real, particularmente en Francia e Inglaterra y en otro texto apegado estrictamente al análisis de un periodo histórico concreto intitulado La Sociedad Feudal, publicado en 1939.

Pero no es ahí donde concluye la odisea y la permanencia de la idea de mentalidad, porque esta misma encuentra refugio y difusión fuera de las voces que académicamente le atesoraron. Y quién con ellas se tuvo que confrontar fue ni más ni menos que el holandés Johan Huizinga (1872-1945), el mismo autor del ensayo lúdico sobre la vida social titulado Homo Ludens, quien entre sus antecedentes defendió su obra, con cambiante título (Le Goff 1978b:295), El Otoño de la Edad Media, cuyas líneas estaban inmersas en la descripción de la mentalidad propia de un tiempo histórico, emplazada en los actos de caballería, los gestos y alusiones corteses, las formas amorosas y la estética de las relaciones sociales. Una reflexión sublime y literaria -y sin excesos retóricos ramplones- acerca de la vida social, de los comportamientos que la suceden y de las actitudes colectivas vigentes y rememoradas, así puede resumirse injustamente la obra.

Para los fines que nos atañen, ésta obra recibió, de inicio, una gentil acogida por parte de los dos titulares de la revista de los anales, reconociéndole su valor pionero a la misma, como "psicología histórica" y como "psicología colectiva" (Le Goff 1978b:295); pero al transcurrir de los años, los comentarios serían cada vez más mordaces, evidenciando las preferencias de aquellos por un cierto tipo de aproximación histórica, y que no era esa en la que Huizinga se habría educado, "ciertas tendencias históricas que abominan", según dicen (Le Goff 1978b:296), ya que el trabajo del historiador holandés destilaba influencias adquiridas en su inicial formación, desde lo expuesto por Edward B. Tylor o Jacob Buckhardt, o lo que a Bloch y Febvre, como escuela o corriente de pensamiento, les causaran mayor aversión, los trabajos de Karl Lamprecht o los de Wilhelm Wundt, a quien se le ubica -informalmente-como mentor de Huizinga a su paso por Leipzig (Le Goff 1978b:295, Burke 2000:210).

Dicho lo anterior, no es con miras de una genealogía, lo que sí es que evidencia los porqués del rechazo de esa obra por parte de Bloch y Febvre, consecuencia de la diversidad en los intereses académicos del holandés, pero ante todo de su estilo literario poco serio, lo que le valdría ser tachado, e inmortalizado, por ser un autor que no llega a una “[...] verdadera interdisciplinaridad. Su psicología es meramente 'literaria', su etnología 'filosófica' y su filosofía 'moralizadora' (Le Goff 1978b:295). Algo de lo que adolecen los estudios que presuponen la idea de mentalidad, los cuales conciben que al embelesar con versos literarios o al excederse en la exposición de lugares comunes, "eso" bosqueje una mentalidad.

Como sea, en El Otoño de la Edad Media, son expuestas, con o sin la venia de aquellos, reflexiones que consolidan la idea de mentalidades, como la siguiente, la cual expone el escenario retórico en el que se ampara el pensamiento social, y que señala que: "Todo caso histórico o literario tiene la inclinación a cristalizarse en una parábola" (Huizinga 1973:358); o ésta otra que dice que: "Cuando se piensa con representaciones tan fuertemente aisladas, la mera presencia de una representación en el espíritu basta para admitir su credibilidad" (p.376). Pretextos suficientes para reivindicarle como parte de los orígenes de la noción de mentalidad.

Y quien supo hacerlo de una manera por demás esquemática fue Henri Berr, haciendo de esto una cristalización histórica magistral, y así como Bloch reseño la obra de Lefebvre, el maestro de retórica le otorgó su justa dimensión al trabajo de Febvre, en un afable recuento (1942) hacia la obra cumbre del historiador Lucien Febvre, El Problema de la Incredulidad en el Siglo XVI: La religión de Rabelais, un texto desde el que se desprenden ciertas premisas teóricas hacia la noción de mentalidades, tales como la 
relevancia implícita que bosqueja el entorno social, cultural, o de conocimientos compartidos; así mismo, según lo dicho por Berr, en ese estudio queda expuesta la erudición de Febvre, o mejor dicho, su capacidad para reconfigurar un proyecto de síntesis histórica (p.V), reconocimiento anclado en el abordaje metodológico, inmerso en el cómo y en el quién se habría interesado sobre ese mítico personaje que se bosquejaba en el subtítulo de la obra, cuestionando cada ensayo, testimonio, escrito u alusión que hubiese sido documentada tanto por amigos o enemigos de Rabelais, por sus detractores y críticos, o por los que con él simpatizaban; empero, no omite interrogar al mismo (p.VII), compilando una amplia biografía, que justifica el por qué de acudir a un personaje como aquel. Actitud que Berr aplaude y reivindica así: "Febvre centra su investigación en Rabelais. Y no acuse sorpresa si en una obra destinada a estudiar la evolución de la humanidad, hayamos admitido que un hombre sea el 'centro' de todo un volumen. Esta obra pretende ser explicativa: pues bien, la explicación conlleva el estudio del papel del individuo, ya como intérprete de una época, ya como iniciador del futuro. $Y$ aquí se trata precisamente de saber hasta qué punto este hombre refleja su siglo y hasta qué punto pudo anticipársele y sobrepasarlo" (p.VI-VII).

Aprehender el "espíritu de la época" es resonancia de un proyecto ambicioso, es una provocación al contexto académico contra el que Febvre se confrontaba (véase Burke 1999, Corcuera 2000, Aguirre 2005), polémicas que a Berr fascinaban; y en su relectura cada elemento de la vida social, adquiere su propio matiz, a saber: “[...] va Febvre haciendo desfilar toda clase de ambientes y numerosos personajes. Siguiéndole, dijéramos estar contemplando como un río que, constante en su dirección, va reflejando y bordeando diversas riberas y cambiantes paisajes" (Berr 1959: IX). Desde los poetas y los músicos, desde la gente parapetada en las calles, desde los oficios que recrean sus propios contrastes, desde los teólogos y los libre pensadores, desde los más creyentes hasta los que aparecen como entidades sobrias que causan empatía y buena fe: los infieles incrédulos: "[...] en todos ellos hay personajes a los que Febvre hace revivir en un puñado de páginas o en unas cuantas líneas y que su libro está lleno de referencias y de semblanzas y de retratos" (Berr 1959: X).

Sin perder detalle de la vida social es como Febvre va historizando la realidad, acudiendo al clima afectivo y moral producto de las relaciones humanas (p.XII). Y sobre estas es que el autor acudía para describir la mentalidad incrédula de la época (p.XIII). La incredulidad a la cual acude el historiador Febvre deviene un halo social que aclamó su propia realidad, una realidad que supuso una transición entre las formas de conocer, es decir de aproximación a la misma, y del conocimiento, esto es, de los asentamientos o enclaves, significantes o parábolas, a los cuales se acudía para explicar la propia y la conjunta realidad. Con base en esto, es por lo que Henri Berr proclama a la obra de Febvre como un estudio de "psicología histórica", así es como Berr visualiza futuras investigaciones que podrían ser aludidas como escenarios de "psicología colectiva", en sus palabras: "la principal tarea del historiador" (Berr 1959:XI), apostando por un emplazamiento académico distinto, y que requería una forma distinta de aproximarse a la vida colectiva, descrita en cada uno de los elementos cotidianos que se preservan en las mentalidades.

\section{Psicología histórica y mentalidades colectivas}

Habremos de deambular históricamente con lo sucedido entre décadas para toparnos con la transición del siglo XIX al XX, ya que es ahí cuando esto -el origen psicosocial de las mentalidades- logra detonarse de una forma por demás elegante y sutil, por demás aguerrida, ya que desde los distintos flancos académicos la crítica hacia el positivismo se hizo presente, y no se acude a esto sólo por las múltiples voces disidentes que lo dijeron, mismas que se ubicaban en diversas latitudes geográficas, si no por las áreas de conocimiento 
desde las cuales surgieron, caso concreto el originado a partir de lo que se llamó la "controversia de Lamprecht" (Burke 1999:17), la cual, en resumidas cuentas, y para no cansar al posible lector con pesados pormenores, fue la exposición realizada por un inconforme erudito alemán, un historiador -vanidoso y arrogante según lo han descrito (Jahoda 1995:184) - con tal apellido quién confrontó a esa historia política una simple historia de individuos decía- con aquella otra historia realizada por la propia gente, por el propio pueblo, por sus experiencias o sus desilusiones.

Y cuyo sustento teórico lo determinaba al ser una disciplina con carga "socio-psicológica", esto aún cuando la rimbombante noción con miras a ser acuñada no estuviera referida institucionalmente, no hay que olvidar que está aparece, como tal, a partir de las descripciones hechas en el siglo XX (Alvaro y Garrido 2003). Lo cual tampoco nos aporta mucha información, ya que lo abstracto del término derivó en una confusión academicista sobre el qué, cómo y por qué de la psicología social, una discusión que obvió o dejó de interesarse por esos planteamientos precursores. Intentando contextualizar lo anterior se puede señalar: “Al final del siglo XIX, algunos historiadores profesionales no estaban satisfechos con el predominio de lo político. Uno de los más elocuentes fue Karl Lamprecht, que criticó al establishment histórico alemán por su énfasis en la historia política y en la historia de los grandes hombres, y propugnaba por una 'historia colectiva' que tomara sus conceptos de otras disciplinas. Estas disciplinas incluían la psicología social de Wundt y la 'geografía humana' de Ratzel, ambos compañeros de Lamprecht en la Universidad de Leipzig" (Burke 1987:24).

Fortuito entrecruce que nos permite remontar aquellas inquietudes interdisciplinares propias de la época. Y aunque de Wilhelm Wundt ya se ha escrito y de sus obras ya se ha polemizado, con algo de buenas intenciones se le puede reivindicar como aquel personaje cuyas aportaciones a la psicología social son necesarias para volverla a revisitar. Caso contrario al de Frederich Ratzel, la otra influencia letrada de Lamprecht, quien acuñó el término de "geografía humana", e introdujo una noción fundamental en el giro que la historia sufrió al confrontarse con los presupuestos académicos imperantes, "Antropogeografía" le llamaría, y de la cual también abrevarían las reflexiones de Wundt con respecto a su Völkerpsychologie (Wundt 1926:5), compartiendo el interés por esa elucubración teórica con el patriarca de la sociología francesa Durkheim, quien deambuló conceptualmente con ésta (Toubert 1988:87), hasta que Henri Berr, un personaje formalmente ajeno a la institución histórica pero interesado férreamente desde la disidencia académica en ella (Corcuera 2000:159), será quien la recupere dentro de su proyecto enciclopédico enfocado a la Historia de la Humanidad, matizándola -los dos-como sinónimo de "Morfología Social".

Generando una especie de retórica combativa, producto de la polémica académica y del interés interdisciplinar existente en la época, y que sufriría embates a partir de discretos espacios donde se discutían otras maneras de reflexionar sobre la vida social. Por caso, aquel emplazamiento permeado con discusiones acerca del medievalismo, la antropogeografía y la völkerpsychologie, llamado L' historisch geographische Seminar con sede en Leipzig donde tanto Lamprecht, Ratzel y Wundt discutían sus ideas e intercambiaban datos (un seminario que se vuelve pieza clave por la influencia que ejerce en los alumnos que a este acudieron), desde 1898 hasta la muerte del geógrafo en 1904 (Toubert 1988:62). Un dato curioso que permite visualizar el intercambio que entonces se realizaba, tal como éste otro; el hecho de que por las mismas fechas - mejor dicho, la misma década- tanto Wundt como Berr, escribieran textos donde confrontaban y comparaban los vestigios culturales y civilizatorios de su país con los de los otros colegas. EI texto de Wundt Ilamado La Evolución de las Filosofías de los Pueblos (1913), y el de Berr, llamado Le Germanisme contre I'Esprit français. Essai de Psychologie historique, fechado en 1919 (Berr 1925: XXVII), 
valga entonces ésta mención como un antecedente para la propia historia de la psicología social. Sirva a la vez para reflexionar por el significado primigenio de lo psicosocial, anclado en este escrito a partir de una psicología colectiva, que a su vez puede leerse como una psicología histórica.

Como sea, estos fueron algunos de los senderos que las reflexiones psicohistóricas tuvieron que sustentar, o confrontar según sea el caso, para llegar a proponer una manera distinta de abordar los fenómenos históricos, el entrecruce y la validación interdisciplinar.

\section{Conclusiones}

La exposición anterior intercede por un entrecruce disciplinar añejo, tanto como la conversación sugerida entre aquellos interlocutores preocupados por debatir, bajo las plumas y estilos que ésta polémica se bosquejó. Por un lado, la que pone a discusión los orígenes dichos sobre la psicología social, y que tan chabacanamente se ha desplazado al olvido institucional, porque pareciera que sólo los que se reconocen bajo ese apelativo son los portadores y los precursores de decir, señalar o imponer la versión más conveniente para sus proyectos y legitimaciones (Alvaro y Garrido 2003), develando un ejercicio didáctico pero a la vez exclusivo con respecto al campo de conocimiento que se expone en sus palabras; y es que cualquier omisión crea un malentendido, cualquier sustracción u adición modifica la comprensión de un escenario posible, en el caso de la psicología y la psicología social, eso sucede a partir del desdén de su historia, al nulo reconocimiento que se hace a las entrelíneas de la misma, y si a las partes selectivamente subrayadas sobre sus fundadores y sus tan ad hoc "objetos de estudio".

A partir de esto se reencuentra el sendero trazado por la psicología colectiva, y de su transición primigenia, allende los siglos, una psicología interesada en las irrupciones y en la presencia de los fenómenos colectivos, en su permanencia y su disolución, y es ésta la versión primigenia de psicología social (Arciga 1989:19), que en el siglo XX se desdibujó. Y la historia de la psicología apenas la considera como antecedente teórico o metodológico, mucho menos como un apartado afectivo e histórico, responsable único, eso sí, de nostalgias y sentimentalismos por aquellas entidades que el cientificismo psicológico del siglo imperante logró disolver (Fernández 1989), o que enquistó en discursos llenos de tecnicismos, que según decían, a partir de los mismos era posible aprehender la realidad, el fenómeno, la emotividad o el pensamiento que podía pensar a esa misma sociedad.

Sin embargo, la paradoja disciplinar es ésta, si la psicología prescindía de estas entidades y de los comportamientos psicosociales y las actitudes que las amparaban, éstas serían acogidas por aquellos escenarios colindantes que las ciencias humanas y sociales bosquejaban, los históricos (White 2001, Burke 1999); los antropológicos y lingüísticos (Jahoda 1995), y por supuesto los literarios y liminares (Béguin 1996, Berlin 2004, De Paz 2003). Involucrándose en cada uno con cierta tesitura y fluidez, recreando escenarios y vivencias (de lo que se vio, de lo que se escuchó, de lo que fue indicio de rumor), acotando incertidumbres, gestando otras aproximaciones hacia la realidad circundante, provocando malestares a partir de la personificación de las multitudes, las leyendas, los mitos urbanos o callejeros, y los ensayos cotidianos plasmados de afectividad colectiva.

Una idea, una tradición, una historia, son los referentes del origen psicosocial de las mentalidades. Una idea que convocaba y amparaba a los grupos, describía la vida social, repensaba a la colectividad, fluctuaba entre los hábitos y la descripción de la realidad circundante. Dando paso a una tradición nostálgica de psicología social llamada psicología histórica o colectiva. Tradición que permite reeditar la historia de la disciplina 
psicosocial, al sugerir otros escenarios, otros precursores, otros horizontes. Confrontando lo dicho sobre la misma, revisitando planteamientos con posibilidades de tornar comprensible la realidad contemporánea. Convocando para ésta discusión una historia, una tradición y una idea descritas por distintas voces, literarias en ocasiones, combativas en otras; recreando atmósferas, describiendo y polemizando sobre algún acontecimiento o fenómeno social.

Aquí no hay conceptos últimos, lo que sí, hay historias y relatos de una disciplina, hay nostalgias por lo que se hizo y que tristemente se difuminó, y eso, es parte de las responsabilidades disciplinares que cada cual asume hacia su campo de conocimiento, más allá de dar la noción exacta o el término correcto, se intenta preservar allende los intentos por omitirlos las entrelíneas que remontan el pasado, la historia, los entrecruces, las omisiones que provocan inconformidades hacia las versiones institucionalizadas de la historia de la psicología y la psicología social.

Una provocación al lector, y una molestia hacia aquellos que no estén de acuerdo con lo hasta aquí escrito, ya que la finalidad de cada disciplina es la polémica que pueda causar hacia sus adentros, sus orígenes, sus presupuestos, sus delimitantes, sus presupuestos epistemológicos u ontológicos, su saber de qué va, en su indefinición constante, esa que pareciera es la causante de un resquemor académico, y que algunos se empecinan en elucubrar, al imponer sólo una historia, una idea, una aproximación.

En la historia de la psicología y la psicología social logran identificarse muchas de éstas prácticas, esas mismas que intentan omitir o desdeñar escenarios o relatos posibles e igualmente válidos a los que oficialmente se han magnificado, e intentos interesantísimos por ahondar en ello han sido expuestos, en el caso del presente texto, de manera indirecta, la referencia que le circunda es hacia la inaprensibilidad inmersa en la noción de mentalidad, en la discreción de los elementos que pudiesen describirles, y que van desde las prácticas y los hábitos que circunscriben culturalmente a una comunidad hasta los prejuicios y el conocimiento lego al cual acudir para describir personajes, emplazamientos y dinámicas grupales; deambula entre los afectos, aquellos que acuden a la templanza, otros más que recrean miedos implícitos y pánicos colectivos, hasta la descripción y rememoración grupal y conjunta de situaciones y eventos cotidianos que se reelaboran a través de nuevas narrativas.

Algo que logra confluir en lo que en algún tiempo se reconoció como la psicología de las multitudes, emplazamiento teórico que de todo ello abrevaba, del temor y del miedo (Delumeau 2002), de la fascinación y del conservadurismo que el andar masivo provocaba (Le Bon 1895, 1911, 1939), de los contrastes eufóricos de las muchedumbres y de su nulo apego a lo que de estas se decía, y que durante todo el siglo XX continuaron en los escritos y en las conciencias eruditas, en manuales o en recuentos (Stoetzel 1970, Rudé 1998, Moscovici 1993, Vázquez 2004); reeditando comportamientos, hábitos y prácticas cotidianas, relatos que describían esas manifestaciones colectivas; develando las formas sociales a las que éstas acudían (Farge 1994, Burke 2000).

Una idea inmersa en el entrecruce histórico y psicosocial. Un escenario latente que la psicología social podría remontar, y al hacer un recuento se bosquejan entrecruces, caso concreto, el de la psicología social con la historia, la antropología y la sociología, sumatoria disciplinar que en el mejor de los casos, o porque así suena mejor, fue acuñada como psicología colectiva. 
Siendo éste no más que un entrecruce disciplinar que nos permite reconsiderar los orígenes tanto de lo psicológico como de lo psicosocial, cuyas historias y versiones son ya conocidas (Collier, Minton y Reynolds 1996, Alvaro y Garrido 2003), ya que antepone lo histórico y lo literario (White 2001, Corcuera 2000), como precursores en la aproximación a la vida social. Siendo estos escenarios dispuestos e interrogantes relativos al actuar común y cotidiano, concerniente con lo extraordinario y lo permanente, sobre lo inesperado del actuar de los grupos o por la incertidumbre del asentamiento y la adopción de las tradiciones y costumbres. Sobre lo impactante de sus escenificaciones y apelando a que siempre serían distintas, renovadas y originales. Y eso no tenía cabida si no bajo una sola idea: mentalidad.

Un emplazamiento que bajo el resguardo histórico se fue gestando, de la mano y contracara del positivismo imperante que los cánones de la época dictaban (véase Burke 1999, Corcuera 2000, Aguirre 2005), empero la transformación de aquellos presupuestos disciplinares bosquejaron un apartado distinto de reflexiones que sobre los apartados históricos, la vida social y las maneras de abordarla y acuñarla se consolidaron.

Eso es lo que le torna interesante, porque entre historias una disciplina, y sus límites, puede ser nuevamente considerada, bosquejada con nuevas líneas, diversas historias y senderos distintos a los que comúnmente se acudía, concebido en la templanza de los fenómenos colectivos, de las formas sociales, de las dinámicas gestadas y amparadas en el largo plazo, del pensamiento social emplazado en las prácticas sociales.

\section{Bibliografía}

Aguirre, C. 2005. La "Escuela" de los Annales. Ayer, hoy, mañana. México: Contrahistorias.

Alvaro, J. L. y Garrido, A. 2003. Psicología Social. Perspectivas psicológicas y sociológicas. Madrid: Mc Graw Hill.

Arciga, S. 1989. Masas y Públicos. En: P. Fernández (comp.). Psicología Colectiva y Cultura Cotidiana. México: UNAM.

Béguin, A. 1996 (1939). El Alma Romántica y el Sueño. Ensayo sobre el romanticismo alemán y la poesía francesa. México: FCE.

Berr, H. 1925. La Evolución de la Humanidad. Síntesis Histórica. Barcelona: Editorial Cervantes.

Berr, H. 1959 (1942). Prólogo: Psicología Colectiva y razón individual. En: L. Febvre. El Problema de la Incredulidad en el Siglo XVI. La religión de Rabelais. México: UTEHA.

Berlin, I. 2004. Las Raíces del Romanticismo. Madrid: Taurus.

Bloch, M. 1999. Historia e historiadores. Madrid: Akal.

Boring, E. G. 1950. Historia de la Psicología Experimental. México: Trillas.

Burke, P. 1987. Sociología e Historia. Madrid: Alianza Editorial.

Burke, P. 1999. La Revolución Historiográfica Francesa. La Escuela de los annales: 1929-1989. Barcelona: Gedisa. 
Burke, P. 2000. Formas de Historia Cultural. Madrid: Alianza Editorial.

Chartier, R. 2003. Espacio público, Crítica y Desacralización en el Siglo XVIII. Los Orígenes culturales de la Revolución Francesa. Barcelona: Gedisa.

Corcuera de Mancera, S. 2000. Voces y Silencios de la Historia. Siglos XIX y XX. México: FCE.

Collier, G, Minton H. L. y Reynolds, G. 1996. Escenarios y Tendencias de la Psicología Social. Madrid: Tecnos.

Delumeau, J. 2002. El Miedo en Occidente (Siglos XIV-XVIII). Una ciudad sitiada. Madrid: Taurus.

De Paz, A. 2003. La Revolución Romántica. Poéticas, estéticas e ideologías. Madrid: Tecnos/Alianza.

Duby, G. 2004. Historia de las mentalidades. En: B. Rojas. Obras selectas de George Duby. México: FCE.

Farge, A. 1994. La Vida Frágil. Violencia, poderes y solidaridades en el París del siglo XVIII. México: Instituto Mora.

Farr, R. 1996. The Roots of Modern Social Psychology. 1872-1954. Cambridge: Blackwell Publishers.

Fernández, P. 1989. Las Tradiciones de la Psicología Colectiva. Fundamentos y Crónicas de la Psicología Social Mexicana 1(1): 38-77.

Fernández, P. 2001. Introducción y notas a una psicología perdida. En: M. A. González y J. Mendoza. Significados Colectivos. Procesos y reflexiones teóricas. México: CIIACSO/Tec de Monterrey-Campus Estado de México.

Ginzburg, C. 1984. Prólogo a la edición italiana de I Re Taumaturghi de Marc Bloch. Argumentos 1(26): 17-25.

Huizinga, J. 1973 (1929). El Otoño de la Edad Media. Estudios sobre las formas de la vida y del espíritu durante los siglos XIV y XV en Francia y en los Países Bajos. Madrid: Revista de Occidente.

Jahoda, G. 1995. Encrucijadas entre la Cultura y la Mente. Continuidades y cambio en las teorías de la naturaleza humana. Madrid: Visor.

Le Bon, G. 1963 (1895). Psicología de las Multitudes. México: Divulgación.

Le Bon, G. 1939 (с.1906). La Revolución Francesa y la Psicología de las Revoluciones. Santiago: Editorial Chile.

Le Bon, G. 1911. Les Opinions et les Croyances. Disponible en www.classiques.uqac.ca

Lefebvre, G. 1986 (1939). El Gran Pánico de 1789. La Revolución Francesa y los campesinos. Barcelona: Paidós.

Le Goff, J. 1980. Las mentalidades. Una historia ambigua. En: J. Le Goff y P. Nora. Hacer la historia. Vol III. Barcelona: Laia.

Le Goff, J. 1978a. La Nueva Historia. En: J. Le Goff, R. Chartier y J. Revel. La Nueva Historia. Bilbao: Mensajero. 
Le Goff, J. 1978b. Huizinga. En: J. Le Goff, R. Chartier y J. Revel. La Nueva Historia. Bilbao: Mensajero.

Le Goff, J. s. d. Prólogo. En: M. Bloch. 2006 (1924). Los Reyes Taumaturgos. Estudio sobre el carácter sobrenatural atribuido al poder real, particularmente en Francia e Inglaterra. México: FCE.

Moscovici, S. 1993. La Era de las Multitudes. Un tratado histórico de la psicología de las masas. México: FCE.

Moya, L. 1996. Vida cotidiana y mentalidades en la escuela de los Annales. Sociológica 11(31): 61-77.

Muñoz, J. y Vázquez, F. 2004. Procesos colectivos y acción social. En: F. Vázquez Psicología del Comportamiento Colectivo. Barcelona: Editorial UOC.

Ortega, S. 1991. Introducción a la Historia de las Mentalidades. En: H. Crespo, et al., El Historiador frente a la Historia. México: UNAM.

Revel, J. 1978. Henri Berr. En: J. Le Goff, R. Chartier y J. Revel. La Nueva Historia. Bilbao: Mensajero.

Revel, J. 2002. Las Construcciones Francesas del Pasado. Argentina: FCE.

Rudé, G. 1998. La Multitud en la Historia. Los disturbios populares en Francia e Inglaterra 1730-1848. México: Editorial Siglo XXI.

Stoetzel, J. 1970. Psicología Social. Valencia: Marfil.

Suárez, R. 2006. Gustave Le Bon y el espíritu de la psicología social. En: S. Arciga, et al., Miradas Psicosociales a la Realidad. México: SOMEPSO.

Toubert, P. 1988. Prefacio a Les Caracteres Originaux de L'Histoire Rurale Française de Marc Bloch. Argumentos 1(26): 59-90.

Vázquez, F. 2004. Psicología del Comportamiento Colectivo. Barcelona: Editorial UOC.

White, H. 2001. Metahistoria. La Imaginación histórica en la Europa del siglo XIX. México. FCE.

Wundt. W. 1912. Elementos de Psicología de los Pueblos. Bosquejo de una historia de la evolución psicológica de la humanidad. Barcelona. Alta Fulla. 1990 (Reproducción en facsímil de la edición original en español: Madrid. Editorial Daniel Jorro. 1926).

Wundt, W. 1926 (1913). La Evolución de las Filosofías de los Pueblos. Madrid: Daniel Jorro.

Recibido el 27 Dic 2008

Aceptado el 5 Feb 2009 